\title{
Research, action and 'critical' geographies
}

\author{
R M Kitchin* and P J Hubbardt \\ *Department of Geography, National University of Ireland, Maynooth, County Kildare, Ireland. \\ Email: rob.kitchin@may.ie. †Department of Geography, Loughborough University, \\ Loughborough LE11 3TU. Email: p.j.hubbard@|lboro.ac.uk
}

In the 1990s, the notion of 'doing' critical geographies has become one of the central themes infusing human geographic study. Eschewing the strictures of radical Marxist approaches (which principally focused on the forms of oppression and inequality wrought by capitalist process), critical geography has consequently sought to examine the diverse sociospatial processes that regulate and reproduce social exclusion. The lens of critical geographers has thus widened from a narrow focus on capital-labour relations to encompass broader processes of social disadvantage and marginalization as they affect women, ethnic minorities, sexual dissidents, disabled people and so on. Simultaneously, this 'critical agenda' has been accompanied by a heightened concern that the geographer's research on social oppression and exclusion should be sensitive to the life experiences of marginalized groups. For example, in recent years there have been several papers (eg Keith 1992; Robinson 1994; Rose 1997) and collections (Canadian Ceographer 1993; Professional Geographer 1994; Antipode 1995) that have examined issues such as reflexivity, empowerment, emancipation, critical praxis, positionality and power relations. Such writing has generally concentrated on the complex social relations the exist between researcher and researched, with ideas from feminist scholarship (in particular) invoked to dismiss assumptions that research is an objective and 'value-free' endeavour.

Following in this tradition, the papers in this edited issue seek to advance the debate on conducting critical research by considering the extent to which academically motivated research should seek to be (and can be) empowering and emancipatory. While this debate can be addressed on a number of levels, an explicit attempt is made in these papers to explore the extent to which geographers can (or should) become activists, seeking to promote political and social change through actions as well as teaching and writing. Given the current espousal of 'critical' geography as a form of geographical practice that is politically and socially aware, it might be considered surprising that the interface between academia and activism has been little explored in the geographic literature (for exceptions, see Routledge 1996; Chouinard 1997; forthcoming; Kitchin 1999). Indeed, the absence of critical reflection on the merits and limitations of action-led or participatory research indicates that such efforts remain few and far between. As such, it appears that many social and cultural geographers are happy to survey (and 'map') the exclusionary landscape, but rarely do much to change that landscape apart from the occasional token nod to 'planning and policy recommendations'.

Yet, at the same time, anecdotal evidence suggests that many of those who subscribe to the Critical Geography Forum mailing list (and many of those who do not) are involved in activism at all levels. Indeed, CVs of contemporary human geographers might reveal a discipline riddled with hunt saboteurs, anti-road protestors, green activists, charity workers and homeless advocates (not to mention local councillors, community representatives and magistrates). But it appears that most seek to maintain a scholarly 'distance' between their activism and their teaching, research and publishing activities, and do not incorporate such activist concerns into their 'disciplinary' life. Overall, then, while many (or indeed most) geographers now accept that research must recognize the power imbalances that exist between researcher and researched, only a minority explicitly seek to effect change through the marriage of research practice and political and social actions. In this sense, while 'critical' geography promotes (and celebrates) the collapse of boundaries between researcher and researched, employing strategies that will empower marginalized groups to seek justice either themselves or through research, in some 
respects it reasserts the dominant practices of scientific inquiry (particularly the division between study and action). As such, critical geographers may aim to empathize with the researched, seeking to empower and emancipate them through their writing and teaching, but, paradoxically, they rarely join with them in their 'struggle'.

The seeming reticence of geographers to combine their politicized 'personal' interests within their 'public' research lives (and vice versa) is, however, perhaps understandable. Crossing the boundaries between the spaces of activism and academia is inherently problematic. As Bourdieu (1988) notes, the distinction between the pristine 'ivory tower' and the messy world of the 'streets' has been important in maintaining the pedagogical authority of education, an authority that is seen to be compromised when academics attempt to bridge these two worlds (a point echoed in Sibley's 1995 discussion of the partitioning of academic knowledges). Inevitably, this distinction reinforces notions of modernist, rationalist science and seeks to maintain privileges attached to certain types of (academic) knowledge production over alternative ways of gaining understanding. Hence, while critical geographers acknowledge that academic knowledge(s) are produced, situated and politicized, we would argue that they frequently seek to maintain the division between 'gaze' and action in an attempt to (re)assert their 'academic' credentials. This is not to suggest that critical geographers in any way wish to return to the days when geography was patrician and patriarchal, but merely to stress that in an era of increasing educational regulation and competition, making connections between action and research is discouraged by a wider culture of academic production (see especially Sidaway 1997). Such a position suggests that overt political commitment should be left at the college gates, and that the 'outputs' of academic labour should be papers in refereed journals with an international audiencenot seditious rants or polemics in fanzines (things that might actually get read by people outside the spaces of academia) - and certainly not 'actions'.

Therefore, we wish to preface this collection of papers by arguing that human geography-as a 'critical' practice-needs to consider the 'place' of the activist within the academy. A central plank in our argument here is that the adoption of so-called 'action research' methods may offer a route for geographers to combine a role of activist with that of putative academic. As the papers in this issue acknowledge, the adoption of research that tries explicitly to tackle oppression, exclusion and injustice is never straightforward, and often places the researcher/activist in a difficult 'third space' (Routledge 1996). Equally, researching from within does not absolve geographers from considering the ethical implications of their research (far from it). However, we merely wish to suggest that if critical geography is serious about its (emancipatory) intentions, then it needs to reconceptualize how it can engage (and participate) with marginalized populations, opening new, alternative routes for 'doing' geography.

Admittedly, this argument is not particularly original, and numerous social scientists have also identified the need to bridge the chasm that still exists between radical, academic theorists and 'on-theground' activists (Pfeil 1994). For example, Touraine (1985) has described the importance of 'committed research', Katz (1992) has spoken of a 'politics of engagement', while hooks (1994) has described an 'ethics of struggle' that exists both within the academy and beyond. At the extreme, some have suggested that 'unapplied' knowledge is knowledge shorn of its meaning and that, by failing to engage with 'on-the-ground' politics that will improve the human condition, the academic becomes guilty of 'systematized selfishness' (Dickson 1982, cited in Mohan 1996). Routledge (1996) has expressed similar concerns, questioning the current social responsibility of academics given their training, access to information and freedom of expression. Such a perspective views the academy as a body that takes, but gives little (if anything) in return. On the contrary, critical geography could be about give and take. As Chouinard $(1994,5)$ argues:

\footnotetext{
This means putting ourselves 'on the line' as academics who will not go along with the latest 'fashion' simply because it sells, and who take seriously the notion that 'knowledge is power'. It means as well personal decisions to put one's abilities at the disposal of groups at the margins of and outside academia. This is not taking the 'moral high ground' but simply saying that if you want to help in struggles against opposition you have to 'connect' with the trenches.
}

As Chouinard stresses, it is easy to get carried away with the idea that activism is, by definition, a 'good thing' and, equally, that a geography conducted on the 'front line' (to continue her military metaphor) is 'better' or morally superior than that conducted at a distance. Indeed, we certainly do not want to give this impression. Nonetheless, following Chouinard 
and others, we feel that there needs to be more room within the discipline for those who want to combine their roles as academic and activist in the pursuit of a truly 'critical' geography.

The papers that follow therefore detail five attempts to conduct emancipatory and empowering critical geographies of social exclusion that, in very different ways, extended the role of the 'academic' beyond the traditional role as researcher. Specifically, the papers by lan Maxey, Keith Halfacree and Duncan Fuller detail their experiences of conducting research on subjects with which they had a personal involvement as activists. In the other two papers, by Phil Hubbard and Lisa Doyle, the potentials and pitfalls of adopting an activist role as a means of conducting emancipatory research with marginalized groups are explored. The papers (with the exception of lan Maxey's) were all presented at a Social and Cultural Geography Research Group session on 'Social exclusion/social action', convened at the RGS-IBG 1998 Annual Conference. Though uneven in tone and subject matter, the collection provided a useful springboard for attendees to discuss the frustrations and challenges, as well as senses of progress and 'justice', that they associated with action-oriented and participatory research. We hope they prove equally stimulating in the context of this journal.

The first paper-'Beyond boundaries? Activism, academia, reflexivity and research'-explores activism as a discursively produced concept. Here, Ian Maxey examines the relationship between academic and activist through his experiences of several different actions. Maxey details that activism, as with academia, is produced by the actors within (activists) and outside (press, state, business, individuals with vested interests) its boundaries and, as an enterprise, can be exclusionary. As he recognizes, being situated within both academia and activism can lead to conflicting dilemmas, but ones which can be resolved through the process of reflexivity and a recognition that academic and activist roles are fluid, not separate. He suggests that we are all engaged in the process of activism as we live our daily lives, and, through engaged critical reflexivity, this can be realized and situated in relation to academic roles.

In "'Anarchy doesn't work unless you think about it": intellectual interpretation and DIY culture', Halfacree uses Maffesoli's theory of neotribes to explore 'cultures of resistance' in 1990s Britain, illustrating his argument through a case study of the occupation (in which he took part) of derelict land in
London by The Land Is Ours, a direct action group. He suggests that a more reciprocal relationship needs to develop between theory and practice (academia/activists), so that actions on the ground learn from theories of DIY culture, whilst theories of DIY culture recognize and examine the nature of action on the ground. Whilst not speaking from a 'third space' between academia and activism, Halfacree suggests that such a positioning allows us to understand activism and the role of theory in informing activism.

Fuller, in his paper 'Part of the action, or "going native"? Learning to cope with the "politics of integration"', details the experiences of a transfer of role from a detached, participant observer of credit union development to an active union member committed to aiding successful development. He describes his process of learning to cope through reflexivity as he sought to establish his identity as a researcher, given that he had compromised the traditional research practice of separating researcher from researched. $\mathrm{He}$ concludes that academia and activism are not mutually exclusive, and, through a recognition and use of the researcher's multiple positionality (as person, as academic, as activist), ethnographic research is strengthened, not weakened.

This process of negotiating an appropriate research/activist role is also explicitly addressed in Phil Hubbard's 'Researching female sex work: reflections on geographical exclusion, critical methodologies and "useful" knowledge'. Here, the author describes how his intention to develop a critical geography of sex work was problematized by his status as a male academic distanced from female prostitutes by his class, age, gender and sexuality. He subsequently describes the way in which his work with this 'hidden' and stigmatized group was complicated by his difficulty in accessing, let alone being able to empathize and work with, this population. Describing a series of abortive research efforts, Hubbard concludes by describing how his research subsequently developed along more traditional lines, seeking to problematize any simple assertion that action research is the only way of doing 'critical' geography. Here, by raising questions about what is 'useful' geographical knowledge, the author stresses that every researcher needs to interrogate their own positionality carefully in order to decide how they can best make a contribution to debates surrounding the oppression and exploitation of excluded groups, emphasizing that the activist/researcher role is not always an easy one to adopt and maintain. 
More positively, Lisa Doyle, in 'The Big Issue: empowering homeless women through academic research?', describes her experiences while constructing a critical geography of homeless women in three UK cities. In the process of conducting her research, Doyle encountered a number of ethical and research dilemmas that led her to question the extent to which her research was fulfilling its aim of being emancipatory and fulfilling her own political goals of addressing a pertinent issue of social justice. Doyle concludes that research addressing issues of social exclusion and involving the use of agencies for data access inherently becomes a negotiated process full of dilemmas that can only be resolved through reflexive understanding of the complex interplay of actors (researcher, researched, agencies), intentions (emancipation, charity, saviour) and situation (transitory population, hostels, fear/ anxiety). While the research was not as emancipatory as was originally intended, and difficult to instigate, it has provided homeless women with a voice into debates about their lives.

To the authors/activists who present their work here, it seems that the process of geographic research is as much about changing the world through their own actions as it is about studying the world. Part of this process of seeking change is to engage in 'on-the-ground' practical politics with (and for) those who are oppressed and excluded within society. Another facet is to engage in more inclusive forms of research through partnership projects where power is devolved so that the researched become co-researchers (see Chouinard 1997; Kitchin 1999). Collectively, these papers consider how we might construct emancipatory and empowering geographies that incorporate explicit modes of action; in effect, they begin to explore the 'third space' of critical engagement between academia and activist (see Routledge 1996). As they imply, this space offers intriguing opportunities for constructing, performing and disseminating 'critical' geography, yet it needs to be carefully negotiated. It is hoped that the following papers will inspire other critical geographers to marry professional and personal politics and engage in on-the-ground activism, thus providing insights that will help guide critical geographers in such a pursuit.

\section{References}

Antipode (1995) 'Symposium on feminist participatory research' Antipode 27, 71-101
Bourdieu P (1988) Homo academicus (Polity Press, Cambridge)

Canadian Ceographer (1993) 'Focus: feminism as method' Canadian Geographer 37, 48-61

Chouinard $V(1994)$ 'Editorial: reinventing radical geography: is all that's Left right?' Environment and Planning $D$ : Society and Space 12, 2-6

- (1997) 'Editorial: making space for disabling differences: challenging ableist geographies' Environment and Planning D: Society and Space 15, 2-6

- (forthcoming) 'Getting ethical: for inclusive and engaged geographies of disability' Ethics, Place and Environment

Dickson A (1982) 'Study service: for other countries, other institutions, other people's children-or for ourselves?' in $S$ Godland (ed) Study service: an examination of community service as a method of study in higher education (NFER-Nelson, Windsor), 7-33

hooks b (1994) Teaching to transgress (Routledge, New York)

Katz C (1992) 'All the world is staged: intellectuals and the projects of ethnography' Environment and Planning $D$ : Society and Space 10, 495-510

Keith $M$ (1992) 'Angry writing: (re)presenting the unethical world of the ethnographer' Environment and Planning D: Society and Space 10, 551-68

Kitchin R M (1999) 'Ethics and morals in geographical studies of disability' in Proctor J and Smith D (eds) Geography and ethics: journeys through a moral terrain (Routledge, London), 223-36

Mohan J (1996) 'Geographies of welfare and the welfare of (British) geography' Paper presented at the Second British-Georgian Geographical Seminar, Birmingham University, 28 June -5 July

Pfeil F (1994) No basta teorizar: in-difference to solidarity in contemporary fiction, theory and practice' in Grewel I and Kaplan C (eds) Scattered hegemonies (University of Minnesota Press, Minneapolis), 197-230

Professional Geographer (1994) 'Women in the field: critical feminist methodologies and theoretical perspectives' Professional Geographer 46, 54-102

Robinson J (1994) 'White women researching/representing others: from anti-apartheid to postcolonialism' in Blunt A and Rose $G$ (eds) Writing, women and space (Guilford Press, New York), 197-226

Rose G (1997) 'Situating knowledge: positionality, reflexivity and other tactics' Progress in Human Geography 21 305-20

Routledge $\mathbf{P}$ (1996) 'The third space as critical engagement' Antipode 28(4), 399-419

Sibley D (1995) Geographies of exclusion: society and difference in the West (Routledge, London)

Sidaway J D (1997) 'The production of British geography' Transactions of the Institute of British Geographers 22(4), 488-505

Touraine A (1985) 'An introduction to the study of social movements' Social Research 52, 749-87 